\title{
BATARI HYANG JANAPATI DALAM PERSPEKTIF GENDER
}

Batari Hyang Janapati in Gender Persfective

\section{Elis Suryani N.S.}

Universitas Padjadjaran

Pos-el: elis.suryani@gmail.com

Abstrak: Kehidupan masyarakat Indonesia dominan dengan budaya patriarki yang menempatkan perempuan selalu berada di bawah bayang-bayang laki-laki. Dalam, persepsi struktur sosial masyarakat, perempuan selalu dipandang sebelah mata. Di Indonesia juga ditengarai banyak perempuan yang tertindas dan dilecehkan. Perempuan dalam budaya patriarki selalu dianggap tidak berdaya dan harus selalu bergantung kepada laki-laki, dalam pribahasa bahasa Sunda, ada pribahasa "awewe mah dulang tinande" yang berarti mengharuskan perempuan ada dalam kelas kedua setelah laki-laki. Dalam kehidupan sehari-hari, perempuan diposisikan ada dalam ranah domestik, yang aktivitas dan perkerjaanya dibatasi hanya seputar sumur, dapur dan kasur. Tugas perempuan hanya melayani suami, berada di rumah dan mengurus anak. Namun saat ini, seiring dengan kemajuan dan perkembangan jaman, peran dan kedudukan perempuan mulai berubah menuju kesejajaran dan kesetaraan. Dominannya budaya patriarki di Indonesia, bertolak belakang dengan beberapa catatan naskah dan prasasti Sunda kuno, ternyata ada perempuan Sunda zaman dahulu sudah memiliki semangat kesejajaran dan kesetaraan dengan laki-laki. Sosok perempuan ini merupakan sosok yang gagah berani, pandai, cerdik, cendekia, seorang panglima perang yang gagah berani, tangkas dan cekatan, sekaligus seorang batari 'guru agama' pada zamannya, sebagaimana terungkap dalam Prasasti Geger Hanjuang dan Naskah Amanat Galunggung bernama Batari Hyang Janapati. Tulisan ini bertujuan mengungkap masalah gender yang terkuak lewat naskah dan prasasti Sunda, dilihat dari peran, kedudukan, dan motif yang melatarbelakanginya, melalui pendekatan gender dalam sosial, sastra, dan budaya yang ada dalam naskah dan prasasti.

Kata Kunci: Batari Hyang Janapati, Peran dan kedudukan, Kajian Gender

Abstract: The life of Indonesian society is dominant with patriarchal culture that puts women always under the shadow of men. In, the perception of social structure of society, women are always underestimated. In Indonesia, many women are also oppressed and abused. Women in a patriarchal culture are always considered helpless and should always be dependent on men, in the Sundanese language proverb, there is an "awewe mah dulang tinande" proverb which means that women are in the second class after men. In everyday life, women are positioned in the domestic sphere, whose 
activities and work are limited only around wells, kitchens and mattresses. Women's duties only serve the husband, are at home and take care of the child. But now, along with the progress and development of the era, the role and position of women began to change toward equality and equality. The dominance of patriarchal culture in Indonesia, in contrast to some ancient Sundanese script and inscription records, it turns out there are ancient Sundanese women already have the spirit of equality and equality with men. The figure of this woman is a brave, clever, ingenious figure, intellectual, a brave warlord, agile and nimble, as well as a batari 'religious teacher' in his day, as revealed in the Inscription Geger Hanjuang and Galunggung Mandate Text is named Batari Hyang Janapati. This paper aims to reveal the gender issues revealed through Sundanese texts and inscriptions, judging by the role, position, and motives behind them, through the gender approaches in social, literary, and cultural contexts in texts and inscriptions.

Keywords: Batari Hyang Janapati, role and position, gender study

How to cite: Suryani, Elis. (2017). Batari Hyang Janapati dalam Perspektif Gender. Jentera: Jurnal Kajian Sastra. 6 (2), 164-180. (doi: 10.26499/rnh.v6i2.100)

\section{Pendahuluan}

Keanekaragaman budaya yang dimiliki masyarakat Jawa Barat merupakan unsur kebudayaan nasional yang dapat memberikan corak dan karakteristik kepribadian bangsa. Penggalian dan pengembangan budaya daerah, membutuhkan data dan informasi selengkap mungkin sehingga dapat dilihat sebagai satu perwujudan kesatuan kebudayaan nasional. Sumber informasi budaya yang sangat penting dalam rangka perwujudan kesatuan budaya nasional di Jawa Barat adalah naskah dan prasasti. Keduanya dapat dipandang sebagai dokumen budaya karena berisi berbagai data dan informasi ide, pikiran, perasaan, pengetahuan sejarah, serta budaya dari bangsa atau sekelompok sosial budaya tertentu. Selain itu, naskah dan prasasti termasuk dalam unsur budaya yang erat kaitannya dengan kehidupan sosial budaya masyarakat yang melahirkan dan mendukungnya.
Budaya masa lalu sedikitnya berguna untuk mengungkap 'tonggak' bagi suatu kehidupan masyarakat tertentu yang sama-sama dijalaninya. Itu sebabnya, naskah dan prasasti Sunda mampu menguak tabir, khususnya yang berkaitan dengan perempuan hebat di masa lalu, yakni Ratu Galunggung Batari Hyang Janapati yang dalam tulisan ini akan dilihat dari segi gender. Tulisan ini bertujuan mengungkap masalah gender yang muncul lewat naskah dan prasasti Sunda, dilihat dari peran, kedudukan, dan motif yang melatarbelakanginya, melalui pendekatan gender dalam sosial, sastra, dan budaya yang ada dalam naskah dan prasasti. Fokus penelitian ini adalah untuk mengungkap bagaimana peran, perilaku, tugas, hak dan fungsi yang dibebankan kepada Batari Hyang Janapati sebagai seorang perempuan yang tercatat dalam karya sastra Sunda lama, baik itu yang berada dalam catatan naskah kuno maupun prasasti. 
Penelitian gender yang berkaitan dengan tokoh dan peran perempuan dalam masyarakat Sunda, pernah dilakukan penulis pada tahun 2002 (Suryani, dkk.), penelitian tersebut berjudul Peran Perempuan Sunda dalam Karya Sastra Sunda: Suatu Kajian Gender. Penelitian penulis saat itu mengkaji empat karya sastra Sunda, yaitu Puputon, Baruang Ka Nu Ngarora, Lain Eta, dan Pipisahan, yang didanai oleh Pusat Bahasa Departemen Pendidikan Nasional. Pada tahun 2002 penelitian tersebut diterbitkan menjadi buku, dengan judul yang sama. Buku tersebut mengkaji tokoh-tokoh karya sastra melalui deskripsi secara struktural, motif tingkah laku, norma, persepsi, dan peran perempuan.

Riset-riset khusus mengenai tokoh perempuan Sunda dalam kajian gender kebanyakan dilakukan dalam penelitian skripsi mahasiswa diantaranya Jurusan Sastra Sunda Fakultas Ilmu Budaya Universitas Padjadjaran dan Jurusan Pendidikan Bahasa dan Sastra Daerah Univeristas Pendidikan Indonesia. Namun mereka kebanyakan tidak secara khusus mengkaji 'gender' secara mendalam, hanya sebatas deskripsi teori dan uraian sepintas. Pada umumnya mereka mengkaji sastra melalui pendekatan struktur atau sosiologi sastra secara umum. Padahal, kajian gender terhadap perempuan Sunda perlu didalami lebih jauh untuk menghasilkan simpulan penelitian yang bisa menjadi pegangan mengenai peranan perempuan Sunda.
Mencermati

perempuanperempuan hebat di masa lalu seperti Ratu Sima, Ken Dedes, Batari Hyang Janapati, dan tokoh lainnya yang terungkap dalam naskah. Tidak mengherankan apabila di era globalisasi kini, muncul sosok perempuan hebat yang menduduki kedudukan dan posisi yang tidak kalah pentingnya dari laki-laki, baik sebagai menteri, profesor, manajer, gubernur, bupati, maupun jabatan strategis lainnya. Tampilnya perempuanperempuan di ranah publik tidak lepas dari peran modernisasi dan kemajuan zaman yang membuka persaingan tanpa membeda-bedakan gender.

Dengan demikian, tidak mengherankan juga apabila saat ini, kita mengenal tokoh dan pahlawan perempuan seperti Rd. Ajeng Kartini, Cut Nyak Dien, Cristina Martha T., maupun Rd. Dewi Sartika, sebagai perempuan hebat pada masanya yang berjuang bagi sesamanya maupun bagi bangsa dan negara. Perempuanperempuan hebat itu dapat dianggap sebagai 'srikandi-srikandi' penerus 'tokoh' perempuan sebagaimana terungkap dalam naskah dan prasasti.

Perempuan dalam masyarakat tradisional lebih bersifat introvert. Mereka lebih bereaksi lewat hatinya tanpa diwujudkan dalam tindakannya. Tatkala dihadapkan pada peran suami yang dominan, para istri lebih bersifat menerima, karena keterikatannya secara ekonomi dan sosial. Sosok perempuan dalam masyarakat masa kini, umumnya masih memperlihatkan adanya bentukan yang lahir dari sosok 
perempuan tradisional. Dikaitkan dengan latar, cara, dan tujuan, tindakan yang dilakukannya karena adanya keterikatan perempuan akan lingkungannya.

Beragam peristiwa yang dihadapi sosok perempuan mengimplikasikan bahwa setiap perempuan mengetahui keberadaan dan kemampuan dirinya dalam menghadapi tantangan hidupnya. Namun, para perempuan menempuh cara yang berbeda dalam memperoleh pengakuan dirinya, kekuatan, kepercayaan diri, kemandirian, dan kebebasan. Sebagian cara ditempuh secara normatif. Meskipun dalam beberapa kasus, tidak jarang dilakukan tindakan yang keluar dari aturan adat, hukum, maupun norma moral, dikarenakan tidak puas terhadap harga dirinya. Hal ini pun sebenarnya tidak seratus persen berbeda dengan zaman dahulu. Sebagaimana kita simak dari motif dan perilaku Batari Hyang Janapati sesuai dengan peran dan kedudukannya sebagai perempuan, istri, ibu, Ratu Galunggung, panglima angkatan perang, dan juga sebagai guru agama pada masanya.

Tulisan ini hanya sekadar mencermati 'peran perempuan' yang berkaitan dengan masalah 'gender', terutama yang terungkap dalam tradisi tulis yang dalam tulisan ini dikhususkan terhadap tokoh yang bernama Batari Hyang Janapati, yang diarahkan kepada fungsi dan kedudukan 'perempuan' sebagai istri, ibu, dan anak. Fungsi itu dijalankan dan diarahkan kepada lingkungan @2017, Jentera, Volume 6, Nomor 2 keluarga dan lingkungan terdekatnya, tempat di mana seorang perempuan melakukan fungsi sosialnya, baik dalam keluarga maupun dalam masyarakatnya.

Metode penelitian yang digunakan berupa deskriptif persepsional analisis melalui penggambaran objektif faktual. Berikutnya, data dipersepsi sesuai dengan tujuan. Persepsi penelitian yang dimaksud diarahkan pada pemahaman gender berdasarkan pengamatan tekstual kehidupan sosial budaya yang tertuang dalam naskah atau prasasti, maupun pengamatan sosial budaya yang nyata dan sesuai dengan data.

\section{Landasan Teori}

Persepsi diartikan sebagai tanggapan melalui proses indrawi sejalan dengan tahapan berikutnya melalui penelusuran motif, norma, dan persepsi tokoh. Bias-bias gender dapat ditemukan melalui pemahaman terhadap hubungan timbal balik antara motif dan persepsi dalam lingkup norma yang umumnya melegitimasi keberadaan penyifatan dari tokoh Batari Hyang Janapati maupun tokoh lainnya.

Menurut Mansour Fakih (1996: 7) kata gender dalam bahasa Indonesia dipinjam dari bahasa Inggris. Kalau dilihat dalam kamus, tidak secara jelas dibedakan pengertian kata sex dan gender. Sementara itu, belum ada uraian yang mampu menjelaskan secara singkat dan jelas mengenai konsep gender dan mengapa konsep tersebut penting guna 
memahami sistem ketidakadilan sosial. Dengan kata lain timbulnya ketidakjelasan itu disebabkan oleh kurangnya penjelaan tentang kaitan antara konsep gender dengan masalah ketidakadilan lainnya.Untuk memahami konsep gender harus dibe dakan kata gender dengan kata sex (jenis kelamin). Pengertian jenis kelamin merupakan pensifatan atau pembagian dua jenis kelamin manusia yang ditentukan secara biologi yang me lekat pada jenis kelamin tertentu.

Adapun menurut Suharti (1995) yakni gender tentu berbeda dengan seks. Seks adalah jenis kelamin laki-laki dan perempuan yang dilihat secara biologis. Sedangkan gender adalah perbedaan laki-laki dan perempuan dilihat dari segi sosial, masalah atau isu yang berkaitan dengan peran, perilaku, tugas, hak dan fungsi yang dibebankan kepada perempuan dan laki-laki. Biasanya isu gender muncul sebagai akibat suatu kondisi yang menunjukkan kesenjangan antar gender.

Istilah gender mengacu pada perbedaan-perbedaan antara perempuan dan laki-laki tanpa konotasi yang sepenuhnya bersifat biologis. Maka rumusan gender dalam hal ini merujuk kepada beberapa perbedaan antara perempuan dengan laki-laki yang merupakan bentuk sosial, perbedaan-perbedaan yang muncul meskipun tidak disebabkan oleh perbedaan biologis, yang menyangkut jenis kelamin (McDonald dkk., 1999).

Perempuan menurut konsep tradisional harus tunduk, patuh, serta setia kepada suaminya. Lewat struktur ini pula sistem patriarki diberlakukan, sehingga tampak nyata perbedaan kedudukan antara perempuan dan pria dalam hal pemerolehan status keturunan dan kekuasaan dalam rumah tangga. Status perempuan dalam masyarakat tradisional, dinyatakan lewat hal-hal yang telah dicapai suaminya, baik kekuasaan, kekayaan, maupun kedudukan. Oleh karenanya, sikap dan perilaku dalam menjalankan fungsinya sebagai istri atau ibu pada umumnya, bergantung pada keberadaan suaminya, sehingga terjadi pembatasan kebebasan. Seluruh kehidupannya cenderung diarahkan kepada soal keluarga dan rumah tangga. Seorang istri berupaya mencapai kedudukannya melalui keberadaan atau kegiatan suaminya. Dalam hal ini, sistem patriarki, kedudukan perempuan melekat pada status suaminya. Lebih jauhnya lagi, terdapat ciri ketergantungan perempuan kepada pria dalam hal ekonomi, status sosial, dan mental.

\section{Hasil dan Pembahasan}

\subsection{Esensi Tokoh Batari Hyang Janapati dalan Naskah dan Prasasti}

Sesuai dengan fitrahnya, perempuan merupakan sosok manusia yang ditakdirkan untuk melahirkan keturunan, hamil, melahirkan, menyusui, semua itu adalah hal yang tidak bisa dilakukan oleh seorang pria. 
Tugas perempuan menurut anggapan patriarki hanya sebatas ibu rumah tangga yang bertanggung jawab untuk mengasuh dan mendidik anak, serta melayani suami menjadi tugasnya seumur hidup.

Perkembangan zaman yang berubah sesuai dengan perkembangan ilmu pengetahuan, teknologi, pemikiran, dan kemajuan sosial. Maka peran dan kedudukan perempuan pun ikut berubah. Kedudukan perempuan saat ini sudah setara dan sedejarat dengan kaum pria dalam dunia pekerjaan dan kehidupan sehari-hari. Kesejajaran antara laki-laki dan perempuan tidak hanya berlangsung saat ini. Namun pada tahun 1111 masehi terdapat perempuan Sunda yang pandai, seorang cendekia, seorang panglima perang yang gagah berani, tangkas dan cekatan, sekaligus seorang batari -ulama/guru agamapada zamannya, sebagaimana terungkap dalam Naskah Amanat Galunggung dan Prasasti Geger Hanjuang. Sosok perempuan yang dimaksud adalah seorang ratu yang

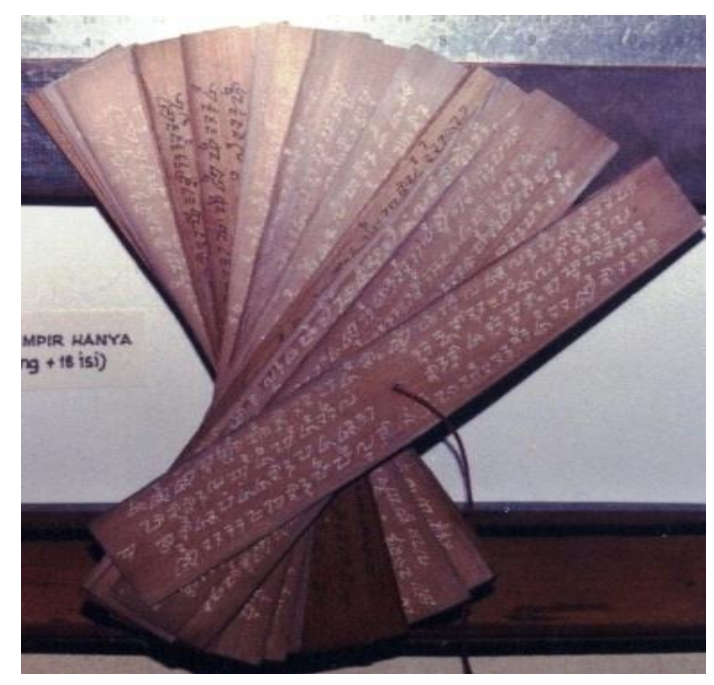

Gambar 1: Naskah Lontar Amanat Galunggung

@2017, Jentera, Volume 6, Nomor 2 memegang takhta kerajaan di daerah Galunggung bernama Batari Hyang Janapati.

Naskah Amanat Galunggung erat kaitannya dengan Prasasti Geger Hanjuang, karena dalam isinya terdapat kesesuaian yang berkenaan dengan pembuatan parit -sungai- sebagai pertahanan Rumantak pada masa pemerintahan Batari Hyang Janapati yang bertahta di Galunggung. Seperti terdapat dalam cuplikan naskah Amanat Galunggung:

Awignam astu. Nihan tembey sakakala Rahyang Banga, masa sya nyusuk na Pakwan makarangan Rhyangta Wuwus. (1-2) Danasasmita, dkk (1989: Halaman 119).

Semoga selamat. Inilah permulaan tanda peringatan RaHyang Banga, ketika ia membuat parit (pertahanan) Pakuan, bernama Rahyangta Wuwus.

\section{Naskah Amanat Galunggung} (AG) milik Perpustakaan Nasional sebelumnya naskah ini ditempatkan di Museum Nasional yang termasuk dalam koleksi Brandes dengan nomor kropak 632). Holle yang pertama kali membahas naskah AG ini, hanya sampai baris ke-4 lempir ke-4 (Darsa, 1991: 25; Suryani, 2007). Kemudian Pleyte dan Poerbatjaraka mencantumkan lagi dan mengoreksi hingga keseluruhan teksnya tuntas.

Esensi Amanat Galunggung berisi tentang ajaran hidup yang diwujudkan dalam bentuk nasihat yang dituturkan oleh Rakeyan Darmasiksa kepada putranya, Sang Lumahing Taman, beserta cucu, cicit, dan keturunannya 
yang umumnya bagi masyarakat luas. Menurut salah satu karya Pangeran Wangsakerta, Rakeyan Darmasiksa adalah seorang raja Sunda yang memerintah tahun 1175--1297 Masehi, mula-mula berkedudukan di Saunggalah yang lokasinya termasuk daerah Galunggung, kemudian pindah ke Pakuan. Berdasarkan hal ini pula, Danasasmita memberi judul Amanat Galunggung.

Danasasmita memberikannya judul Amanat Galunggung karena memang sesuai pula dengan keseluruhan isi naskah ini. Naskah Amanat Galunggung berkaitan erat dengan Prasasti Geger Hanjuang karena isinya ada kesesuaian berkenaan dengan pembuatan parit (pertahanan) Rumantak pada masa pemerintahan Batari Hyang Janapati yang bertahta di Galunggung. Naskah Amanat Galunggung dan Prasasti Geger Hanjuang pun memiliki korelasi dengan Hari Jadi Tasikmalaya yang dibuat pada tanggal 21 Agustus 1111 Masehi, sebagai tanda upacara pentasbihan 'penobatan' Batari Hyang Janapati sebagai penguasa dan bertahta di Galunggung. Dengan demikian, Prasasti Geger Hanjuang mampu membuktikan bahwa cerita rakyat/sastra lisan yang tersebar dan berkembang di sekitar Galunggung yang ditengarai hampir punah, ternyata benar-benar terbukti dan ada, hal ini menjadi sebuah pembuktian nyata kepada masyarakat Tasikmalaya.
Pada saat itu pula di tahun 1111 Masehi Kerajaan Galunggung yang semula berbentuk kebataraan diperintah oleh Batari Hyang Janapati seorang perempuan berjiwa prajurit yang cerdas, tangkas, cekatan, dan 'nyantri'. Dia dikenal sebagai seorang prajurit handal yang mengauasai daerah Galunggung. Dia ikut andil memperkuat pertahanan ibukota kerajaan dengan parit.

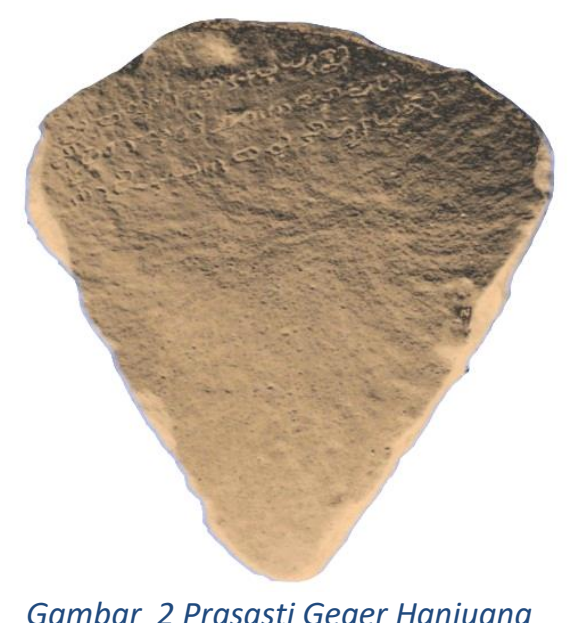

Prasasti Geger Hanjuang yang berkaitan dengan tokoh Batari Hyang Janapati merupakan patokan dalam rangka menelusuri Hari Jadi Tasikmalaya. Prasasti tersebut merupakan tetengger 'tonggak' yang dapat dipercaya dan dipertanggungjawabkan keabsahannya. Pertama kali prasasti itu dibaca Holle, kemudian dikoreksi oleh Pleyte. Danasasmita pernah melakukan pembacaan kembali disertai koreksi dan pembahasan secara mendalam. Prasasti tersebut ditemukan di bukit Geger Hanjuang, Desa Linggawangi, Leuwisari Kecamatan Singaparna, Kabupaten Tasikmalaya. Prasasti yang dimaksud, kini tersimpan di Museum Pusat Jakarta dengan 
nomor koleksi D-26, berukuran tinggi $80 \mathrm{~cm}$ dan lebarnya $60 \mathrm{~cm}$.

Prasasti Geger Hanjuang isinya ditulis dalam aksara dan bahasa Sunda kuno yang cukup jelas untuk dibaca, terdiri atas tiga baris yang bacaannya sebagai berikut:

tra ba i gunna apuy na-

sta gomati sakakala rumata-

$k$ disusu ( $k$ ) $k$ u batari hyang pun

Tafsirannya:

'Pada hari ke-13 bulan Badra tahun 1033 Saka Rumatak

(selesai) disusuk oleh Batari Hyang.'

Berdasarkan silsilahnya, disebutkan bahwa pengganti Sri Jayabhupati adalah Sang Darmaraja dengan nama penobatan Prabu Darmaraja Jayamanahen Wisnumurti Sakalasundabuana. Di awal pemerintahannya, terjadilah pemberontakan yang dipimpin Sang Wikramajaya, panglima angkatan laut kerajaan Sunda. Dia berusaha merebut kekuasaan dari saudara seayahnya, tetapi dapat ditumpasnya. Wikramajaya pun melarikan diri ke kerajaan Sriwijaya. Jabatan panglima angkatan laut diserahkan kepada Sang Wirakusumah, atas kesetiaannya kepada Maharaja Darmaraja.

Wilayah Galuh yang dipercayakan kepada Dewi Sumbadra dapat menjalankan pemerintahan sebagaimana mestinya. Dewi Sumbadra menjadi penguasa kerajaan Galuh sampai tahun 1065 M, selama 38 tahun. Dia diganti oleh putranya Prabu Arya Tunggalningrat yang berkuasa sampai tahun 1091 M. Putrinya bernama Dewi Surastri, menjadi @2017, Jentera, Volume 6, Nomor 2 permaisuri Sang Maharaja Darmaraja. Dari pernikahannya dengan Dewi Surastri, Sang Maharaja Darmaraja berputra, di antaranya:

1. Prabu Langlangbumi

2. Darmanagara (mangkubumi kerajaan)

3. Wirayuda (panglima angkatan perang)

Salah seorang putra Sri Jayabhupati dari Dewi Pertiwi adalah Sang Resiguru Batara Hyang Purnawijaya. Dia berputra beberapa orang, di antaranya:

1. Dewi Puspawati

2. Dewi Citrawati alias Batari Hyang Janapati

Tahap awal adalah berupa penelusuran tokoh Batari Hyang Janapati tentang dirinya, pria atau suaminya, orang tua, anaknya, kerabat atau juga lainnya yang berkaitan dengan dirinya. Batari Hyang Janapati nama sebenarnya adalah Dewi Citrawati, salah seorang putri dari Sang Resiguru Batari Hyang Purnawijaya, yang merupakan cucu dari Sri Jayabupati dan Dewi Pertiwi.

Dewi Puspawati kakak dari Batari Hyang Janapati diperistri oleh Prabu Langlangbumi, sedangkan Dewi Citrawati juga mengharapkan menjadi istri Prabu Langlangbumi. Oleh karena itu, timbul hasrat dari Dewi Citrawati alias Batari Hyang Janapati untuk membunuh kakaknya. Melihat perselisihan kedua putrinya, Sang Purnawijaya (ayah Batari Hyang) mengawinkan Dewi Citrawati kepada 
Resiguru Sudakarmawisesa (penguasa Kebataraan Galunggung). Akan tetapi, setelah perkawinannya dengan Dewi Citrawati, Sang Resiguru Sudakarmawisesa menyerahkan tahtanya kepada istrinya dengan nama nobat Batari Hyang Janapati. Karena Sang Resiguru Sudakarmawisesa memilih jalan hidup untuk mendalami keagamaan dengan menjadi seorang Resi ${ }^{1}$.

Berdasarkan dari hasil bacaan penulis dalam Naskah Carita Parahyangan maka didapatkan kesimpulan cerita seperti di bawah ini.

Di pedesaan antara wilayah Galuh, Sunda, dan Galunggung, tingkat keamanannya menjadi rawan, akibat ulah kawanan perampok. Kerawanan tersebut menyebabkan perselisihan antara Prabu Langlangbumi suami dari kakaknya Batari Hyang Janapati dengan penguasa Galunggung saat itu yang mana adalah dirinya sendiri.

Sebutan 'Batari Hyang' sebagai penguasa Galunggung berkaitan erat dengan predikat 'Batari' yang digunakan untuk menyebut seseorang yang tinggi martabatnya dalam bidang keagamaan. Hal tersebut sesuai dengan kedudukan Batari Hyang Janapati itu sendiri, karena selain seorang perempuan luar biasa, seorang Ratu Galunggung yang cerdas dan perkasa, dan panglima perang yang handal, pembuat parit/benteng pertahanan Rumantak. Kebatarian yang dimilikinya berkenaan dengan kedudukannya

\footnotetext{
${ }^{1}$ Resi berarti pendeta
}

@2017, Jentera, Volume 6, Nomor 2 sebagai 'guru agama' yang digelari Sang Sadu Jati bagi rakyat dan raja-raja keturunannya, sehingga ajarannya dijadikan ajaran resmi pada masanya di Galunggung. Dengan demikian, tidak berlebihan jika dia juga layak digelari Siliwangi (ratu yang harum namanya) seperti raja-raja lain yang telah mampu ngretakeun urang reya ${ }^{2}$ yang bergelar Prabu Siliwangi. Sosok Batari Hyang Janapati sebagai guru agama tersebut ditemukan melalui naskah Amanat Galunggung (Atja, dkk. 1989) yang mengungkapkan bahwa di Kabuyutan Galunggung, ditemukan 'patilasan' semacam 'mandala' berupa padepokan/perguruan.

Padepokan itu menjadi sebuah karesian yang banyak didatangi oleh para santri. Setiap murid wajib 'bertirakat' di padepokan untuk memperoleh kekuatan lahir maupun batin. Selain itu, pernah berkembang dan dibangun sarana peribadatan Mandala Kawikwan, sebagai sarana spiritual untuk melakukan hubungan dengan arwah suci.

Kabuyutan Galunggung pada masa silam disakralkan sebagai pusat kekuatan spiritual yang memiliki energi mistik alam semesta yang paling tinggi di bumi Galunggung. Di Kabuyutan Galunggung tempat berkumpulnya para arwah suci yang dikeramatkan dan disakralkan sebagai tempat menempa jiwa untuk menyiapkan pemuka agama yang handal. Dalam perkembangannya, Kabuyutan Galunggung menjadi sebuah

${ }^{2}$ Bahasa Sunda Kuno artinya mensejahterakan rakyat banyak 
padepokan terbesar di Bumi Galunggung. Berdasarkan hal tersebut, tidak mengherankan jika sampai sekarang, fakta mengungkapkan bahwa di Tasikmalaya terdapat banyak pondok pesantren terkemuka dan terkenal. Sehubungan dengan itu, mungkin warga Tasikmalaya merasa layak pula jika Tasikmalaya digelari sebagai kota Santri.

Selama memegang kekuasaan di Galunggung, Batari Hyang Janapati merasa cemas akan kemungkinan mendapatkan serangan dari Kerajaan Sunda yang dipimpin oleh Prabu Langlangbumi. Untuk mencegah kemungkinan tersebut, Batari Hyang Janapati membentuk angkatan perang, membangun parit pertahanan yang kuat (nyusuk). Kemudian, pusat kerajaan Galunggung dijadikan sebagai ibukota kerajaan Galuh. Selesai membangun ibukota yang baru, Batari Hyang Janapati membuat prasasti, yang kemudian dikenal dengan sebutan Prasasti Geger Hanjuang. Prasasti ini ditemukan di lereng Gunung Galunggung, tepatnya di bukit Geger Hanjuang atau Kabuyutan Linggawangi. Karena prasasti ini semula terletak di Desa Linggawangi, Kecamatan Leuwisari, Kabupaten Tasikmalaya. Prasasti ini sekarang menjadi koleksi Museum Pusat Jakarta, dengan nomor koleksi D. 26.

Rumatak yang dimaksud oleh Prasasti Geger Hanjuang adalah ibukota yang baru untuk Kerajaan Galuh. Penduduk di tempat ditemukannya prasasti tersebut masih mengenalnya sebagai Rumatak.
Sebenarnya Sang Maharaja Langlangbumi tidak berniat menyerang Kerajaan Galunggung. Namun, jika tidak segera diatasi, Galunggung akan menjadi duri dalam daging. Ia pun tidak menghendaki timbulnya perpecahan di antara keturunan Sri Jayabhupati. Tindakan Langlangbumi untuk menjinakkan Batari Hyang Janapati ialah dengan cara mengadakan pendekatan, yang dilakukan oleh ayahanda Batari Hyang Janapati yakni Batara Guru Hyang Purnawijaya, Senapati Suryanagara, Resiguru Sudakarma, DangHyang Guru Darmayasa, Senapati Kusumajaya, Langlangbumi, Mangkubumi Darmanagara, Senapati Wirayuda, Yuwaraja Menakluhur, Permaisuri Puspawati, Batari Hyang Janapati sendiri, dan beberapa ratu bawahan Sunda dan Galuh.

Hasil perundingan jalan damai antar pemimpin tersebut, akhirnya membuahkan kesepakatan: Jawa Barat kembali dibagi dua wilayah kekuasaan:

1. sebelah barat sebagai Kerajaan Sunda, di bawah kekuasaan Prabu Langlangbumi bersama permaisuri

2. sebelah timur sebagai Kerajaan Galuh, di bawah kekuasaan Batari Hyang Janapati, dengan ibukotanya di Galunggung

Peran Batari Hyang Janapati sebagai Ratu Galunggung yang cerdas dan pandai bernegosiasi menghasilkan kesepakatan tersebut. Saat itu tahun 1111 Masehi namun pemikiran dan kedudukannya sudah sepadan dengan 
pemimpin lelaki. Hal ini menandakan bahwa seorang Batari Hyang Janapati mampu mensejajarkan diri dengan laki-laki. Sebagai seorang Ratu, Dia memiliki hak dan kewajiban yang sama dengan kaum laki-laki.

\subsection{Peran, Kedudukan, dan Motif Batari Hyang Janapati dalam Pespektif Gender}

Kehadiran peran seorang perempuan dalam kehidupan sosial di masyarakat, memiliki latar belakang konsep pemikiran yang beragam, yang tidak terlepas dari refleksi masyarakat tatkala perempuan itu hidup, dan masih berpusat pada pemilihan gender. Pemilihan yang dimaksud, secara umum maupun khusus telah menyiratkan adanya pemilahan yang membedakan antara laki-laki dan perempuan berdasarkan strukturalisasi sosiokultural. Peran perempuan ditelusuri melalui motif, norma tingkah laku, dan persepsi lewat karya, yang terungkap dalam naskah dan novel Sunda, yang merupakan cerminan dari masyarakat secara keseluruhan.

Pemahaman terhadap gender yang ada di masyarakat terkadang sering keliru. Hal ini berkaitan dengan hal-hal yang berasal dari konstruksi sosial dan dianggap sebagai kodrat, padahal kemampuan itu dimiliki perempuan sebagai akibat konstruksi sosial kulktural masyarakat. Mengacu pada perbandingan mengenai kemampuan, perempuan masih dianggap emosional, sehingga perempuan kurang mendapat tempat pada posisi yang cukup penting.
Ketidakadilan sering muncul akibat perbedaan ini. Di dalam rumah tangga dapat diamati bagaimana proses pengambilan keputusan; pembagian kerja, dan interaksi antaranggota keluarga; atau masalah lainnya yang masih menampakkan adanya bias-bias gender, seperti marginalisasi, subordinasi pelabelan negatif, dan kekerasan. Oleh karena itu, rumah tangga pun menjadi tempat kritis dalam menyoalisasi ketidakadilan gender yang mungkin saja telah mengakar pada keyakinan bagi kaum laki-laki maupun perempuan (bandingkan Fakih, 1999: 21-23).

Masalah gender sesungguhnya melekat erat dalam peristiwa-peristiwa yang terjadi di masyarakat. Peristiwaperistiwa yang terjadi bergulir dan bersentuhan dengan kehidupan keseharian. Dari rentetan peristiwa, munculah konflik sebagai akibat adanya persinggungan antargender. Melalui konflik inilah bias-bias gender dapat diungkap, bagaimana laki-laki dan perempuan diimplementasikan dengan segala kelengkapan persepsinya tentang perannya itu; bagaimana tingkah laku di dalam, motifnya sejalan dengan pola pikirnya yang direalisasikan lewat perilaku/tindakan di samping nilainilai dan peristiwa penting yang terjadi dalam kehidupannya.

Konflik-konflik dasar yang muncul dalam setiap kehidupan ditafsirkan sebagai fakta sosial pada masanya atau paling tidak sebagai fakta yang mungkin saja terjadi, baik di masa lalu maupun masa sekarang dan 
juga dapat ditemukan ruang-ruang gender dengan beragam konflik rumah tangga yang dikemas berdasarkan perbedaan gender. Sejalan dengan motif tingkah laku, norma, dan persepsi dalam kehidupan bermasyarakat, aktivitas perempuan dalam rumah tangga, dan lingkungan terdekatnya mencerminkan adanya pelekatan terhadap fungsi dan kedudukannya di dalam lingkungan sosialnya. Lewat penelusuran motif tingkah laku, dapat diketahui sejauh mana sikap dan tindakannya dilakukan, digagalkan, atau dipertahankan. Selain itu, diketahui pula dorongan-dorongan macam apa yang dapat membuat 'tokoh-tokoh' di dalamnya melakukan suatu cara atau beragam cara untuk menggapai tujuan yang diharapkannya.

Melalui penelusuran tingkah laku, diketahui pula norma yang berlaku pada peran perempuan di dalamnya, norma-norma yang mengikat perilaku masyarakatnya, serta kedudukan pelaku dalam menjalankan fungsi sosialnya. Adapun persepsi di dalamnya muncul dan dilatarbelakngi oleh strukturisasi sosial yang berhubungan dengan tingkah laku dan norma. Persepsi yang muncul dalam peran perempuan dan laki-laki dibentuk oleh pengetahuan dan pengalaman hidup masing-masing pelaku. Lewat persepsi pula, tingkah laku dapat terwujud secara beragam. Dengan demikian, peran perempuan dalam masyarakatnya, khususnya yang terungkap dalam naskah dan novel Sunda dapat ditelusuri dalam upaya menjalankan fungsi sosialnya.

Menyimak peran perempuan dalam menjalankan fungsinya sebagai istri bagi suaminya, konsep dasarnya telah dimiliki. Hanya dalam pelaksanaanya, sebagian pelaku tidak lagi secara taat asas menjalankan perannya secara benar. Dalam kehidupan rumah tangga, seorang istri, sesuai dengan tugasnya adalah mengurus dan membesarkan anak. Berdasarkan pewarisan nilai-nilai tradisional, mereka sadar bahwa tugas pokok seorang istri adalah mengabdikan diri kepada suami serta mengurus dan membesarkan anak. Dalam menjalankan fungsinya, sebagai seorang istri dan seorang ibu, perempuan berperan penting dalam menunjang dan membantu suami. Mereka umumnya bertugas menyelesaikan beragam urusan keluarga dan rumah tangga. Seorang istri diharapkan berperan aktif dalam membantu suami melakukan pekerjaannya dalam mencari nafkah bagi keluarganya. Dengan memainkan peran tradisional, istri memungkinkan suami mencapai ambisinya serta menempati kedudukan yang cukup diperhitungkan dalam lingkungan sosial yang lebih luas.

\subsubsection{Peran Batari Hyang Janapati}

Batari Hyang Janapati sebagai seorang perempuan, istri, ibu, Ratu Galunggung, sekaligus sebagai panglima perang, memiliki peran ganda. Namun, karena Batari Hyang Janapati memiliki motif tidak mau kalah dari 
Pangeran Langlangbumi yang dicintainya, orang yang dicintainya tersebut malah memilih dan menikahi saudaranya sendiri, maka selalu ada dendam di hati, meskipun Batari Hyang Janapati sudah menjadi seorang Ratu dan panglima perang. Dalam hal ini peran suaminya sebagai 'resi' sungguh sangat penting. Suaminya tersebut terus menerus membimbingnya untuk mengubah diri istrinya, menjadi seorang perempuan yang tangguh bagi kebatariannya, dan sebagai seorang ibu yang bertanggung jawab terhadap suami serta anaknya.

Seorang istri berupaya mencapai kedudukannya melalui keberadaan atau kegiatan suaminya. Dalam hal ini, sistem patriarki, kedudukan perempuan melekat pada status suaminya. Lebih jauhnya lagi, terdapat ciri ketergantungan perempuan kepada pria dalam hal ekonomi, status sosial, dan mental. Oleh sebab itu, wajar jika ada seorang perempuan yang rela berpisah dari suaminya demi mendapatkan seorang pria dari keturunan bangsawan. Demikian pula tindakan seorang ayah, yang memaksa anak perempuannya untuk menikah dengan pria keturunan ningrat demi mempertahankan keturunan kebangsawanannya. Identitas perempuan dalam masyarakat yang tergambar sinetron maupun film, dinyatakan lewat hal-hal yang telah dicapai/dihasilkan suaminya, baik kekuasaan, kekayaan, maupun kedudukan. Oleh karenanya, sikap dan perilaku dalam menjalankan fungsinya sebagai istri atau ibu pada umumnya, bergantung pada @2017, Jentera, Volume 6, Nomor 2 keberadaan suaminya, sehingga terjadi pembatasan kebebasan. Seluruh kehidupannya cenderung diarahkan kepada soal keluarga dan rumah tangga.

Motif tingkah laku yang tampak pada tokoh perempuan dalam hal ini Dewi Citrawati alias Batari Hyang Janapati dengan kakaknya Dewi Puspawati, sungguh sangat berbeda. Hal ini tampak saat Pangeran Langlangbumi menyunting Dewi Puspawati, sementara Batari Hyang Janapati merasa patah hati. Beruntung sekali mereka memiliki ayah yang sangat bijaksana, sehingga Dewi Citrawati akhirnya dinikahkan dengan Resiguru Sudakarmawisesa (penguasa Kebataraan Galunggung).

Motif dan perilaku Batari Hyang Janapati yang berniat membunuh kakaknya sendiri ketika tidak dinikahi oleh Langlangbumi, sebenarnya merupakan benih-benih awal yang menyelimuti hati dan motif Batari Hyang Janapati untuk berbuat selalu ingin mengalahkan Dewi Puspawati dan Pangeran Langlangbumi, meskipun sudah menjadi Ratu Galunggung. Maka dari itu, dia membuat benteng pertahanan, yang kemudian ditulis dalam Prasasti Geger Hanjuang.

Dikaitkan dengan latar, cara, dan tujuan, tindakan yang dilakukannya karena adanya keterikatan Batari Hyang Janapati akan peran, kedudukan, status, serta lingkungannya, dalam hal ini 'kebataraannya'. Tokoh-tokoh perempuan seperti Dewi Puspawati dan khususnya Dewi Citrawati, lebih 
menunjukkan sikap reaktif. Dengan kelabilan hati serta potensinya yang emosional, mereka cenderung lebih mudah terpengaruh oleh lingkungannya. Keadaan tersebut tampak nyata pada saat harus mengambil suatu tindakan. Sikap diamnya lebih didorong oleh rasa takut atau terlalu mempertimbangkan segala sesuatu secara rapi agar tidak menyebabkan dirinya berada dalam kondisi yang dirugikan, seperti saat Dewi Citrawati tidak dipilih untuk menjadi istri Langlangbumi.

Status, peran, dan fungsi perempuan sebagai 'istri' di masa lalu, kehidupannya dicurahkan bagi kepentingan suami dan anak. Hal itu tergambar dalam beragam naskah Sunda bernuansa gender yang banyak mendapat pengaruh Islam, di antaranya Wawacan Piwulang Istri, Wawacan Wulang Krama, Wawacan Barjah, Hikayat Siti Fatimah, Lutung Kasarung, dan Wawacan Rengganis. Di samping itu, dalam novel Sunda Puputon, Pipisahan, Baruang $\mathrm{Ka} \mathrm{Nu}$ Ngarora, dan Lain Eta, meskipun berbeda zaman dan ada nuansa gambaran perempuan kekinian, masih tetap menampilkan sosok perempuan tradisional (Suryani, 2002\& 2015).

\section{Simpulan}

Berdasar data dan fakta sebagaimana terkuak lewat naskah dan prasasti Sunda, dapat diambil simpulan yang berhubungan degan motif tingkah laku, norma yang mengikat tingkah laku persepsi perempuan dan laki-laki, serta peran perempuan yang @2017, Jentera, Volume 6, Nomor 2 dihubungkan dengan pembahasan gender.

Motif tingkah laku yang tampak pada tokoh Batari Hyang Janapati, sebagian besar masih menampilkan adanya bentukan yang lahir dari sosok perempuan tradisional. Dihubungkan dengan latar, cara, dan tujuan dilakukannya suatu perbuatan atau tindakan, diperoleh beberapa sifat dasar di dalamnya, yaitu keterikatan perempuan akan lingkungannya. Secara umum, tokoh Batari Hyang Janapati menunjukkan sikap reaktif. Dengan kelabilan hati serta potensinya yang emosional (ketika Batari Hyang Janapati berniat hendak membunuh kakaknya sendiri, karena merasa tersaingi, dan tidak dipilih menjadi istri Langlangbumi), Batari Hyang Janapati lebih mudah terpengaruh oleh perasaan sakit hati dan kelabilan hatinya, serta lingkungannya. Tindakan reaktifnya juga tampak nyata pada saat harus mengambil suatu tindakan.

Sikap diamnya pun lebih didorong oleh rasa takut dan malu atau terlalu mempertimbangkan segala sesuatunya secara rapi, agar tidak menyebabkan dirinya berada dalam kondisi yang dirugikan, karena dalam dirinya masih ada motif membalas dendam kepada Langlangbumi, yang tidak menjadikan Batara Hyang Janapati sebagai istrinya, tapi malah memilih kakaknya sendiri (Dewi Puspawati). Dalam masalah ini pun telah terjadi ragam persepsi yang berhubungan dengan masalah harga diri, yang bermuara pada hal penghormatan kepada diri sendiri dan 
penghargaan dari dan kepada orang lain. Batari Hyang Janapati dalam hal ini merasa tidak dihargai oleh Langlangbumi, malah dilecehkan, karena menolak dirinya, dan merasa malu oleh kakaknya yang dipilih menjadi isrinya Langlangbumi, yang mengetahui isi hatinya, bahwa dia sangat menyintai Langlangbumi.

Sikap introvert justru diperlihatkan oleh tokoh kakaknya Batara Hyang Janapati yang bernama Dewi Puspawati. Dia lebih bereaksi dalam hatinya, tanpa lebih banyak direalisasikan melalui tindakan saat menghadapi suatu masalah, karena justru dirinyalah yang dipilih oleh Langbumi, yang dicintai oleh adiknya (Batari Hyang Janapati). Sebenarnya dalam diri Dewi Puspawati terjadi konflik. Karena walau bagaimanapun, Dewi Citrawati adalah adik perempuan yang sangat ia sayangi.

Hal baik yang dapat dicatat dari peran dan kedudukan Batari Hyang Janapati waktu itu, sebagai perempuan pintar dan cerdas, cerdik cendikia, Ratu Galunggung, panglima, perang, dan guru agama dengan julukan Sang Sadu Jati, di samping sebagai istri dan seorang ibu, saat ini banyak bermunculan perempuan-perempuan hebat di berbagai bidang di Bumi Pertiwi tercinta kita ini, yang lebih dikenal sebagai 'srikandi-srikandi' penerus Batari Hyang Janapati. Peran dan kedudukan mereka kini sudah sejajar dengan kaum laki-laki.

Di era globalisasi kini, kesejajaran peran dan kedudukan perempuan dan laki-laki dimaksud berada dalam @2017, Jentera, Volume 6, Nomor 2 berbagai bidang. Saat ini banyak perempuan yang menduduki jabatan dan memegang kendali yang setaraf dengan pria. Dengan demikian, peran dan kedudukan perempuan pun sudah sangat berbeda. Tetapi mungkin pula ada sebagian yang masih tetap sama, tergantung bagaimana kita menyikapinya. Setinggi apapun kedudukan seorang 'perempuan', dia tetap seorang istri, ibu, dan 'perempuan' yang bertanggung jawab terhadap pekerjaan rumah dan keluarganya. Itulah "kodrat" perempuan sepanjang masa. Dengan kecanggihan teknologi masa kini, mampukah perempuan mengubah kodratnya? Tanya hati nurani masingmasing.

Ternyata jika kita 'engeuh' terhadap tinggalan budaya masa silam, banyak sekali kearifan lokal yang dapat kita gali dan kita petik saat ini, baik melalui naskah maupun prasasti, atau karya sastra lainnya. Masa lalu bisa dijadikan cermin dan pelajaran berharga yang tiada ternilai harganya.

\section{Daftar Pustaka}

Atja, dan Saleh Danasasmita. (1981). Carita ParaHyangan (Transkripsi, Terjemahan, dan Catatan. Bandung: Proyek Pengembangan Permuseuman Jawa Barat.

Ayatrohaedi. (1981). "Peranan Benda Purbakala dalam Historiografi Tradisional" dalam Majalah Ilmu-Ilmu Sastra Indonesia, Penelitian dan Penerbitan Buku/Majalah Pengetahuan Umum dan Profesi Dep. 
Dik. Bud. Jakarta: Fakultas Sastra Universitas Indonesia.

Danasasmita, Saleh. Ya Nu Nyusuk na Pakwan .Bandung: Lembaga Kebudayaan

Unpad.

Danasasmita, Saleh, dkk. (1987). Sewaka Darma, Sanghyang Siksakandang Karesian, Amanat Galunggung. Transkripsi dan Terjemahan. Bandung: Bagian Proyek Sundanologi.

Darma, Budi. (2011). "Penciptaan Naskah Drama Ambu Hawuk Berdasarkan Tradisi Lisan dan Pesfektif Jender". Jurnal Resital, 12 (1), 55-64.

Ekadjati, Edi Suhardi. (2006). Nu Maranggung Dina Sajarah Sunda. Bandung: Pusat Studi Sunda.

Fakih, Mansoer. 1997. Analisis Gender $\mathcal{E}$ Transformasi Sosial. Yogyakarta: Pustaka Pelajar.

Mandy Mc Donald, E. Sprenger, I Dubel. (1999). Gender dan Perubahan Organisasi. Amsterdam: INSIST dan REMDEC.

Seri Sundalana 5. (2006). Mencari Gerbang Pakuan dan Kajian Lainnya mengenai Budaya Sunda. Bandung: Pusat Studi Sunda.

Sunardjo, Unang, dkk. (1978). (Tim Penyusun). Hari Jadi Tasikmalaya. Tasikmalaya: Pemerintah Daerah TK. II Tasikmalaya.
Suryani NS, Elis. (2011). "Batari Hyang Janapati Pelopor Srikandi Indonesia". Bandung: Fakultas Ilmu Budaya Unpad.

Suryani NS, Elis. (2012). “Awewe Dulang Tinande". Bandung: Opini Pikiran Rakyat.

Suryani NS, Elis. (2016). Srikandi Indonesia. Bandung: Opini Pikiran Rakyat. 